\title{
Oral health self-perception evaluation using mandibular overdenture prosthesis in public health care
}

\author{
Avaliação da auto percepção da saúde bucal utilizando prótese overdenture mandibular em saúde pública
}

Fábio Antonio Villa NOVA ${ }^{1}$

Gláucia Maria Bovi AMBROSANO²

Fabrício Lourenço GEBRIN ${ }^{3}$

Rogério Gonçalves VELASCO ${ }^{4}$

Leandro César RUSSO 5

\section{ABSTRACT}

\section{Objective}

The aim of this study was to evaluate the impact on oral health in patients who used to have conventional lower denture and then started using a model of overdenture prosthesis for the purpose of its use in public health care.

\section{Methods}

For this clinical trial study, 23 volunteers participated in the sample. To stabilize the prosthesis three implants were used and immediately loaded. Only one punch was needed for each implant to be installed, neither a flap nor suture was necessary. To evaluate the oral health selfperception the volunteers answered the OHIP-14 questionnaire twice, the first time before the treatment when they still used the conventional lower denture, and the second time within an average of 36 days after the use of the prosthesis stabilized by the implant/O-ring together. For statistical analysis, exploratory data analysis was initially performed and then the nonparametric Wilcoxon test was applied considering a significance level of $5 \%$.

\section{Results}

The average age of the sample was 57.6 years old $(S D=9.0)$ with a minimum age of 43 and maximum of 74 years old. The results show a significant decrease in all domains after the treatment, functional limitation $(p=0.0002)$, physical pain $(p<0.0001)$, psychological discomfort $(p=0.0002)$, physical disability $(p<0.0001)$, psychological disability $(p=0.0008)$, social disability $(p=0.0431)$ and handicap $(p=0.0015)$.

\section{Conclusion}

It was concluded that the model of overdenture prosthesis improved the volunteers oral health self-perception.

Indexing terms: Dental implants. Mandibular prosthesis. Oral health. Public health.

\section{RESUMO}

\section{Objetivo}

Avaliar o impacto sobre a saúde bucal, em pacientes que utilizavam prótese total inferior convencional após utilizar um modelo de prótese overdenture com a finalidade de utilização em saúde pública.

\section{Métodos}

Este estudo clínico experimental teve a participação de 23 voluntários. Para estabilização da prótese foram utilizados três implantes que foram carregados imediatamente. Cada implante necessitou de apenas uma perfuração para ser instalado, sem abertura de retalho e sutura. Para avaliar a auto percepção em saúde bucal, os voluntários responderam o questionário OHIP-14 duas vezes, a primeira antes do tratamento quando ainda utilizavam a prótese total inferior convencional, e a segunda, com uma média de 36 dias após a utilização da prótese já estabilizada através do conjunto implante/oring. Para a análise estatística inicialmente foi realizada análise exploratória dos dados e a seguir aplicado o teste não paramétrico de Wilcoxon considerando o nível de significância de $5 \%$.

\section{Resultados}

A idade média da amostra foi de 57,6 anos $(\mathrm{dp}=9,0)$ com idade mínima de 43 e máxima de 74 anos. Os resultados mostram que houve diminuição significativa em todos os domínios após o tratamento, limitação funcional $(p=0,0002)$, dor física $(p<0,0001)$, desconforto psicológico $(p=0,0002)$, incapacidade física $(p<0,0001)$, incapacidade psicológica $(p=0,0008)$, incapacidade social $(p=0,0431)$ e deficiência $(p=0,0015)$.

\section{Conclusão}

Concluiu-se que o modelo de prótese overdenture melhorou a auto percepção da saúde bucal dos voluntários. Termos de indicação: Saúde pública. Saúde bucal. Implantes dentários. Prótese mandibular.

Termos de indicação: Implantes dentários. Prótese mandibular. Saúde pública. Saúde bucal.

\footnotetext{
${ }^{1}$ Centro de Especialidades Odontológicas - Tatuí. Praça Adelaide Guedes s/ nº, Tatuí, SP, Brasil. Correspondência para / Correspondence to: FAV NOVA. E-mail: fabio.villanova@yahoo.com.br

${ }^{2}$ Universidade Estadual de Campinas, Faculdade de Odontologia. Piracicaba, SP, Brasil.

${ }^{3}$ Consultório particular. Tatuí, SP, Brasil.

${ }^{4}$ Faculdade São Leopoldo Mandic, Curso de Odontologia, Programa de Pós-Graduação em Implantodontia. Campinas, SP, Brasil.

${ }^{5}$ Prefeitura Municipal de Tatuí, Coordenação de Saúde Bucal. Tatuí, SP, Brasil.
} 


\section{INTRODUCTION}

Totally edentulous patients with high jaw bone resorption have a significant therapeutic problem for prosthetic rehabilitation because, despite the careful making of the denture, in many cases it is not possible to obtain its adequate retention and stability. The lack of stability is associated with decreased neuromuscular control, psychological conditions, bone quality, quantity and insufficient alveolar mucosa or inadequate vestibular sulcus ${ }^{1}$.

Edentulism is defined as the permanent teeth loss in a multifactorial process resulting from biological causes, such as caries, periodontal disease, pulp pathology, oral cancer and trauma, as well as non-biological factors such as professional diagnosis, iatrogenesis, lack of access for dental treatment, individual preference for extraction or even lower cost compared to other treatments ${ }^{2}$.

Chewing has the function of grinding the food to occur swallowing and digestion appropriately. When the food is fragmented into small particles its surface area is increased thus facilitating the enzymatic process in the digestive system. The proper digestion is related to the amount of ground food. Maintenance of chewing performance, which is the measurement of the individual's ability to break food in the number of chewing cycles, is considered a determinant of the individual ability to eat a variety of foods that provide adequate nutritional status ${ }^{3}$. Individuals with impaired chewing change the type of food which may lead to malnutrition ${ }^{4}$.

The rehabilitation of edentulous patients with conventional prosthesis, even if carried out in a technically correct way may not solve the problems completely, neither the functional nor the psychological ones. Approximately 5-20 \% of patients remained dissatisfied after rehabilitation with conventional dentures, the main complaints relate to the aesthetics of upper dentures and the instability of the lower dentures ${ }^{5}$. Therefore, retention and stability of dentures are considered factors that influence the ability to grind food and consequently its selection ${ }^{6}$.

Currently, dental implants have become a treatment option for rehabilitation of totally edentulous patients. Initially, in order to achieve that treatment Brånemark instituted a protocol in which a healing period with no load was an essential requirement for achieving osseoinegration?. However, studies suggest that implants used for supporting mandibular overdenture can have early load application.
Mandibular overdentures supported by two, three, or four implants in the anterior region of the mandible which have as their antagonist total upper dentures have proven to be a successful and predictable treatment option for completely toothless patients ${ }^{9-12}$. Fewer implants, simpler operations and short periods of wound healing may increase patient compliance for treatment ${ }^{13}$.

In Brazil, the Unified Health System (SUS) neither has the proper structure nor is sufficient to absorb the demand for dental care of adults, particularly in older age groups. This is one of the reasons why the teeth that could be recovered are extracted since this is considered the most practical and also the most economical procedure. Most people who lose their teeth feel that they are unable to recover their losses through prostheses, mainly due to the lack of financial resources. In people's daily life, the changes produced by the total loss of teeth should constitute a concern to dental profession. However, the professional approach, in most cases, only considers the biological and restorative prospects, in other words, the recovery of teeth must be held within the principles of the best technique neglecting the effects of tooth loss in the patients' quality of life $e^{14}$.

Despite the advances in public policies for prevention in oral health, the number of toothless and partially toothless patients is still significant. The last national survey on oral health called "SB Brazil 2010 Project" found that in the adult population aged between 35 and 44 in $1.3 \%$ of cases, there is need for dentures in at least one jaw. In older people aged between 65 and $7423.9 \%$ dentures are needed in at least one arcade and $15.4 \%$ need the full double prosthesis. Regarding the selfperception of oral health in the 35-44 age group $41.2 \%$ reported being dissatisfied or very dissatisfied with their oral health, while in the 65-74 age group this situation was reported by $32.5 \%$ of the elderly ${ }^{15}$.

Studies on the oral health condition related to quality of life have shown that diseases and changes in the oral cavity negatively interfere on quality of life and the problems that affect patients who have suffered tooth loss affect both masticatory and psycho- social functions, besides quite negative feelings reports ${ }^{16}$.

In Brazil, the Unified Health System has already been financing removable dentures to repair tooth loss since 2004 by the decree $1.570 / \mathrm{GM}$ of $2004^{17}$. The inclusion of dental implant procedure and prosthetics on implants in the Unified Health System table encouraged the municipalities to offer this type of treatment to the population through the SAS $7182010^{18}$ ordinance. 
Thus, a low cost and technically easy mandibular overdenture model could make the use of implants to stabilize lower dentures for use in the public health system feasible.

\section{METHODS}

The aim of this study was to evaluate the impact on oral health in patients who used to have conventional lower denture and then started using a model of overdenture prosthesis for the purpose of its use in public health care.

This experimental trial was approved by the Ethics in Research of the Faculty of Dentistry of Piracicaba, UNICAMP, under the number 079/2012 and is consistent with the standards and guidelines of Resolution No. 196/96 of the National Health Council ${ }^{19}$ and was conducted on patients referred to Specialized Dental Center in Tatuí (SP) for the rehabilitation of lower dentures. The sample consisted of 23 volunteers, 11 male and 12 female with a mean age of 57.6 years old using lower denture without stability and who had as antagonist the full upper dentures in function and with good stability.

Individuals with persistent problems with conventional dentures because of the reduced and insufficient stability retention of the mandibular prosthesis and who used as antagonist their functional superior dentures with good stability reported and no systemic problems that could hamper the surgery and postoperative were included in the sample.

Subjects who did not authorize the procedure, who had excessive parafunctional activity which could lead to prosthetic tooth wearing or fracture of prostheses and those who reported using or having used bisphosphonates were excluded from sampling.

Self tapping conical profile implants with higher sphere for overdenture system, a $2.0 \mathrm{~mm}$ superior hexagon and higher sphere with a diameter of $1.7 \mathrm{~mm}$ O-ring type were used. They were $3.0 \mathrm{~mm}$ diameter implants, with a length of $15 \mathrm{~mm}$ and a $2.0 \mathrm{~mm}$ transmucosal part. A $2.2 \mathrm{~mm}$ surgical drill was used. The implants were installed by using an abutment driver and a $2 \mathrm{~mm}$ external hexagonal ratchet. The stabilization system used a spherical abutment and a retention insert with a $1.7 \mathrm{~mm}$ O-ring for internal use in the dentures.
For the data collection, volunteers were asked to participate in the study after the explanation of the study's goals as well as the surgery of implant placement and prosthesis. The Term of Consent was introduced in order to get their permission.

After authorization the voluntary answered the self-perception of oral health (OHIP -14) questionnaire developed by Slade ${ }^{20}$ and validated in Brazil in 2005 by Oliveira \& Nadanovsk ${ }^{21}$.

Three implants were used to stabilize the prosthesis, located between the menton foramens. Each implant was installed through a single piercing, neither an opening retail nor a suture was necessary. After installing, three openings were made in the lower denture to fix the O-rings which were placed on the implants that were adhered by the resin, therefore the implants were loaded immediately.

The patient answered the OHIP -14 questionnaire again after 36 days after using the overdenture on average.

Exploratory analysis of the data was initially performed for statistical analysis and then the nonparametric Wilcoxon test was applied considering the 5 $\%$ significance level. The descriptive analysis of the results was performed by BioEstat 5.0 program.

\section{RESULTS}

The average number of days between the two response moments of OHIP -14 questionnaire was 36.60 $(\mathrm{SD}=5.28)$ days, with a minimum of 31 and maximum of 57 days. The mean total score of OHIP -14 when the volunteers were still using the conventional lower denture was 11.22 ( $S D=1.22$ ), with a minimum score of 3.25 and maximum of 20.62. When they already used the overdenture, the mean score was $0.93(S D=1.24)$, with a minimum score of 0.0 and maximum of 3.76 (Table 1).

Table 2 shows that there was a significant decrease in all areas after treatment, functional limitation $(p=0.0002$, physical pain $(p<0.0001)$, psychological discomfort ( $p=0.0002)$, physical disability $(p<0.0001)$, psychological disability $(p=0.0008)$, social disability $(p=$ $0.0431)$ and handicap $(p=0.0015)$.

Table 1. Mean, median, minimum and maximum value from the days of the response of self-perception questionnaires on oral health (OHIP -14) and the total scores of the questionnaire before and after using the overdenture.

\begin{tabular}{lcccc}
\hline & Mean & Median & Minimum & Maximum \\
\hline Days between the responses of the questionnaires & $(\mathrm{SD}=5.28)$ & 35 & 31.00 & 57.00 \\
OHIP -14 using dentures & $11.22(\mathrm{SD}=4.84)$ & 10.84 & 3.25 & 20.62 \\
OHIP -14 using overdenture & $0.93(\mathrm{SD}=1.24)$ & 0.48 & 0.00 & 3.76 \\
\hline
\end{tabular}


Table 2. Median, minimum and maximum scores of self-perception of oral health (OHIP -14) before and after using the overdenture.

\begin{tabular}{|c|c|c|c|c|c|c|c|}
\hline & \multicolumn{2}{|c|}{ Before } & \multicolumn{4}{|c|}{ After } & \multirow[t]{2}{*}{ p-value } \\
\hline & Median & Minimum & Maximum & Median & Minimum & Máximum & \\
\hline Functional limitation & 2.00 & 0.00 & 4.00 & 0.00 & 0.00 & 2.04 & 0.0002 \\
\hline Physical pain & 2.64 & 0.40 & 4.00 & 0.00 & 0.00 & 2.66 & $<0.0001$ \\
\hline Psychological discomfort & 2.00 & 0.00 & 4.00 & 0.00 & 0.00 & 1.10 & 0,0002 \\
\hline Physical disability & 2.56 & 0.00 & 4.00 & 0.00 & 0.00 & 1.00 & $<0.0001$ \\
\hline Psychological disability & 0.60 & 0.00 & 4.00 & 0.00 & 0.00 & 1.20 & 0.0008 \\
\hline Social disability & 0.00 & 0.00 & 2.48 & 0.00 & 0.00 & 0.00 & 0.0431 \\
\hline Handicap & 0.59 & 0.00 & 3.59 & 0.00 & 0.00 & 0.00 & 0.0015 \\
\hline
\end{tabular}

\section{DISCUSSION}

In the past only individuals with higher purchasing power could afford to have quality dental care. A national oral health policy within the Health System in Brazil, established in 2004, has brought major advancements for oral health in the public health service, allowing the population access to specialized dental treatments, including the dentures and providing a terminating service also in minor attention ${ }^{17}$. Oral rehabilitation of tooth loss using dental implant by SUS has been possible since 2010, therefore the financing of this specialty allowed municipalities to provide this service to the population ${ }^{18}$.

Heydecke et al. ${ }^{22}$ reported that overdenture with two implants adds up to $56 \%$ more to the final cost when compared to conventional dentures, however, the quality of life improves by $33 \%$. The overdenture model reported in this paper has relative technical simplicity and low cost, and it was possible to transform lower dentures into overdenture stabilized by 3 implants in one session of about an hour, improving the quality of life associated with oral health.

Mandibular overdentures supported by two, three, or four implants in the anterior mandible with the upper dentures as antagonist can be a successful and predictable treatment option for completely toothless patients $^{9-12}$ and implant treatment in edentulous patients can also control some limitations of conventional prostheses perceived by the patient, such as difficulty chewing hard food or psychological discomfort ${ }^{23}$. Thomason et al..$^{24}$ also found evidence that patients are more satisfied with the implant-supported prostheses than with conventional dentures.

Mandibular overdentures are more satisfactory than conventional dentures, however, problems related to retrospective assessment, lack of control group and aftercare can compromise the results ${ }^{25}$.

The instability of the lower denture is the main complaint among users of this type of protheses ${ }^{5}$ and dentures retention and stability were considered influential factors to the ability to grind food and consequently their selection ${ }^{6}$. The last national oral health survey showed that among patients with dentures in the aged group between 35-44, $41.2 \%$ reported being dissatisfied or very dissatisfied with their oral health, while in the 65-74 age group this situation was reported by $32.5 \%$ of the elderly ${ }^{15}$. In the model proposed in this study, volunteers had better scores in all domains of the questionnaire on self-perception of oral health after using the overdenture with immediate loading supported by three implants.

\section{CONCLUSION}

There was a significant decrease in scores in all OHIP -14 domains with the use of implants to stabilize the lower denture with consequently better perception of oral health and quality of life.

\section{Collaborators}

FAV NOVA participated in the work design, data collection, performing the surgeries and writing the article. GMB AMBROSANO participated in the statistical analysis of the collected data during the research and writing of the article. FL GEBRIN and LC RUSSO participated in the surgeries and writing the article. RG VELASCO supervised the research and participated in the writing of the article. 


\section{REFERENCES}

1. Tarbet WJ, Boone, M, Schmidt NF. Effect of a denture adhesive on complete denture dislodgment during mastication. J Prosthet Dent. 1980;44:374-8.

2. Glossary of prosthodontic terms. J Prosthet Dent. 2005;94(1):10-92.

3. Olthoff LW, van der Bilt A, Bosman F, Kleizen HH. Distribution of particle sizes in food comminuted by human mastication. Arch Oral Biol. 1984;29(11):899-903. doi:10.1016/00039969(84)90089-X

4. Bourne MC. Relation between texture and mastication. J Texture Stud. 2004;35(2):125-43. doi: 10.1111/j.1745-4603.2004. tb00829.x

5. van Waas MAJ. The influence of psychological factors on patient satisfaction with complete dentures. J Prosthet Dent. 1990;63(5):545-8.

6. Pocztaruk RL, Matheus J, Soldatelli M, Frasca LCF, Rivaldo EG, Gavião MBD. Avaliação da mastigação em pacientes com dentição natural e usuários de prótese total suportada por implantes Rev Odontol UNESP. 2009;38(3):169-74.

7. Brånemark P-I. Osseointegration and its experimental background. J Prosthet Dent. 1983;50(3):399-410. doi:10.1016/S00223913(83)80101-2

8. Turkyilmaz I, Tözüm TF, Tumer C. Early versus delayed loading of mandibular implant-supported overdentures: 5-year results. Clin Implant Dent Relat Res. 2010;12(Suppl 1):e39-46. doi: 10.1111/j.1708-8208.2009.00218.x

9. Attard N, Zarb G. Long-term treatment outcomes in edentulous patients with implant overdentures: the Toronto study. Int J Prosthodont. 2004;17(4):425-33. doi: 10.1016/j. prosdent.2004.09.018

10. Naert I, Alsaadi G, van Steenberghe D, Quirynen M. A 10year randomized clinical trial on the influence of splinted and unsplinted oral implants retaining mandibular overdentures: peri-implant outcome. Int J Oral Maxillofac Implants. 2004;9(5):695-702.

11. Meijer H, Raghoebar G, Van't Hof M, Visser A. A controlled clinical trial of implant-retained mandibular overdentures:10 years' results of clinical aspects and aftercare of $\mathrm{IMZ}$ implants and Brånemark implants. Clin Oral Implants Res. 2004;15(4):421-7. doi: 10.1111/j.1600-0501.2004.01024.x

12. Visser A, Meijer $H$, Raghoebar G, Vissink A. Implant-retained mandibular overdentures versus conventional dentures: a 10 years of care and aftercare. Int J Prosthodont. 2006;19(3):271-8.

13. Payne AGT, Tawse-Smith A, Thomson WM, Duncan WD, FRACDS, Kumara R. One-stage surgery and early loading o three implants for maxillary overdentures: a 1-year report. Clin Implant Dent Relat Res. 2004;6(2):61-74.

14. Souza e Silva ME, Villaça EL, Magalhães CS, Ferreira e Ferreira E. Impacto da perda dentária na qualidade de vida. Ciênc. Saúde Coletiva 2010;15(3):841-50. doi: 10.1590/S141381232010000300027
15. Brasil. Ministério da Secretaria de Atenção à Departamento de Atenção Básica. Projeto SB Brasil 2010: resultados principais. Brasília: Ministério da Saúde; 2012 [citado 2014 Mar 10]. Disponível em: <http://dab.saude.gov.br/CNSB/sbbrasil/arquivos/ projeto_sb2010_relatorio_final.pdf>.

16. Barbieri $\mathrm{CH}$, Rapoport. Avaliação da qualidade de vida dos pacientes reabilitados com próteses implanto-muco-suportadas versus próteses totais convencionais. Rev Bras Cir Cabeça Pescoço. 2009;38(2):84-7.

17. Brasil. Portaria n. 1.570/GM. Estabelece critérios, normas e requisitos para a implantação e credenciamento de Centros de Especialidades Odontológicas e Laboratórios Regionais de Próteses Dentárias [online]. Diário Oficial da União, Brasília (DF); 2004 Jul 30 [citado 2014 Mar 15]. Disponível em: <http://dtr2004.saude.gov.br/susdeaz/legislacao/arquivo/62_ Portaria_1570_de_29_07_2004.pdf>.

18. Brasil. Ministério da Saúde. Secretaria de Atenção à Saúde. Portaria n. 718/SAS [online]. Diário Oficial da União, Brasília (DF); 2010 Dez 20 [citado 2014 Mar 15]. Disponível em: <http://bvsms.saude.gov.br/bvs/saudelegis/sas/2010/ prt0718_20_12_2010.html>.

19. Brasil. Ministério da Saúde. Conselho Nacional de Saúde. Resolução n. 196/96. Diário Oficial da União, Brasília (DF); 1996 Out 10 [citado 2014 Mar 15]. Disponível em: <http:// www.datasus.gov.br/conselho/comissoes/etica/Resolucoes.htm. Acesso em 06/03/2011>.

20. Slade GD. Derivation and validation of a short-form oral health impact profile. Community Dent Oral Epidemiol. 1997;25(4):284-90.

21. Oliveira BH, Nadanovsky P. Psychometric properties of the Brazilian version of the Oral Health Impact Profile-short form. Community Dent Oral Epidemiol. 2005; 33(4):307-14. doi: 10.1111/j.16000528.2005.00225.x

22. Heydecke G, Penrod JR, Takanashi Y, Lund JP, Feine JS, Thomason JM. Cost-effectiveness of Mandibular Two-implant Overdentures and Conventional Dentures in the Edentulous Elderly. J Dent Res. 2005;84(9):794-9. doi: 10.1177/154405910508400903

23. Della Vecchia MP, Regis RR, Muglia VA, Souza RF. Oral healthrelated quality of life in conventional and implant-retained complete denture wearers: two case reports. Rev Odontol UNESP, 2009; 38(3): 198-203.

24. Thomason JM, Heydecke G, Feine JS, Ellis JS. How do patients perceive the benefit of reconstructive dentistry with regard to oral health-related quality of life and patient satisfaction? A systematic review. Clin. Oral Impl. Res. 18 (Suppl. 3) 2007; 168188 doi: 10.1111/j.1600-0501.2007.01461.x

25. Assunção WG, Barão VAR, Delben JA, Gomes EA, Tabata LF. A comparison of patient satisfaction between treatment with conventional complete dentures and overdentures in the elderly: a literature review. Journal compilation _ 2009 The Gerodontology Association and Blackwell Munksgaard Ltd, Gerodontology 2010; 27: 154-162.

Received on: 18/1/2015 Final version resubmitted on: 2/4/2015 Approved on: 6/6/2015 
